\title{
Work-related leukemia: a systematic review
}

\author{
Ioannis Polychronakis ${ }^{1 *}$, George Dounias ${ }^{2}$, Vasilios Makropoulos², Elena Riza ${ }^{1}$ and Athena Linos ${ }^{1}$
}

\begin{abstract}
Leukemia is a complex disease, which only became better understood during the last decades following the development of new laboratory techniques and diagnostic methods. Despite our improved understanding of the physiology of the disease, little is yet known about the causes of leukemia. A variety of potential risk factors have been suggested so far, including personal habits and lifestyle, and a wide range of occupational or environmental exposures. A causal association with leukemia has only been documented to date for ionizing radiation, benzene and treatment with cytostatic drugs, but there is an ongoing scientific debate on the possible association of leukemia with a number of other work-related hazards. In this article, we have reviewed scientific studies, published over the past 5 years, which investigated potential associations between leukemia and exposure to occupational risk factors. The systematic literature review took place via electronic databases, using specific search criteria, and independent reviewers have further filtered the search results to identify the number of articles, presented in our paper. A large number of studies included in the review referred to the effects of ionizing radiation, where new data suggest that the effects of exposure to small doses of ionizing radiation should probably be reevaluated. Some other works appear to substantiate a potential association of the disease with certain pesticides. Further research is also suggested regarding the role of infectious agents or exposure to certain chemicals like formaldehyde or butadiene in the pathogenesis of leukemia.
\end{abstract}

Keywords: Leukemia, Exposure, Occupation, Worker, Work-related, Hazard, Risk-factor

\section{Review}

\section{Introduction}

The term "leukemia" refers to a group of diseases with different biological background, clinical presentation, prognosis and response to treatment, characterized by a malignant transformation of hematopoietic cells which produce an abnormal leukemic population (clone) of cells suppressing the production of normal blood cellular components. The disease was first identified in the mid-19th century when different researchers described a common pathology caused by abnormalities of the white blood cells [1], hence the term "Leukemia" which originates from the Greek words "Leuko" (white) and "Haema" (blood). While scientific research has advanced significantly since then as regards to the underlying pathophysiology of the various types of the disease, our knowledge on the causative factors involved in the development of leukemia is still limited.

\footnotetext{
* Correspondence: drjpoly@gmail.com

${ }^{1}$ Department of Hygiene, Epidemiology and Medical Statistics, University of Athens, Medical School, 75 Mikras Asias 115 27, Goudi, Athens, Greece Full list of author information is available at the end of the article
}

Different researchers have proposed a number of potential risk factors for leukemia, but to date exposure to ionizing radiation, alkylating agents and benzene [2] remain the only hazards for which an association with leukemia has been substantiated.

An association between ionizing radiation and leukemia was first assumed in the early 20th century, following the effects of uncontrolled exposure of patients and medical personnel to the radiation used for diagnostic and therapeutic purposes $[1,3]$. Those observations were further corroborated by the findings of Life Span Study (LSS) among the A-Bomb survivors of Hiroshima and Nagasaki [4-7], which persist for decades following exposure to radiation $[8,9]$ and the follow-up studies among cleaningworkers in Chernobyl reactor site [10].

Benzene is according to the current scientific knowledge the second best-documented risk factor for the development of leukemia [11]. Its chemical properties have led to its widespread use as a solvent in a number of industrial applications, and occupational exposure to benzene has been documented for workers in different production sectors i.e. production of chemicals, pharmaceuticals, plastics,
Ciomed Central

(c) 2013 Polychronakis et al.; licensee BioMed Central Ltd. This is an Open Access article distributed under the terms of the Creative Commons Attribution License (http://creativecommons.org/licenses/by/2.0), which permits unrestricted use, distribution, and reproduction in any medium, provided the original work is properly cited. 
synthetic rubbers, paints, oil processing etc. [12-14]. Epidemiological studies have shown a significant association between exposure to Benzene and the incidence of acute myeloid leukemia (AML) [15-17].

Cytostatic drugs, and especially chemotherapeutic regimens containing alkylating agents such as Busulfan, Chlorambucil, Cyclophosphamide etc. used in the treatment of solid organ malignancies are another documented risk factor for developing leukemia, as a number of clinical trials on cancer therapeutics has shown an association between this category of drugs and the development of secondary leukemia [18], particularly AML [19]. Despite their known toxicity to oncology patients and the precautionary measures taken to prevent occupational exposure, a number of workers from different disciplines could be exposed to significant concentrations of cytostatic drugs during their production, transportation, distribution, preparation and administration to patients [20-22]. Nevertheless, little is known regarding the potential effect of this exposure on the risk of developing the disease [23-26].

Taking into account the limited knowledge on its actual causes, the investigation of the role of different work-related risk factors in the development of leukemia would be of great scientific interest, providing valuable insight on the etiology of the disease and the available options for the protection of health of specific categories of workers or the public, given the widespread use of different chemical compounds and technological applications in common consumer products.

The growing number of related publications over the last years indicates an increasing concern of the scientific community and recent studies have presented new information as regards our cumulative experience from the application of different technologies and chemical or biological factors in industry, necessitating a review of the current literature on the subject.

Therefore through this paper we systematically collected and summarized all relevant scientific information that has been published internationally in the English language over the last years, exploring the potential role of occupational "risk factors" in the development of the disease.

\section{Materials and methods}

The article review on the role of occupational risk factors in the development of leukemia took place between September and December 2010. The literature search was carried out via the internet, using the online medical database "Pubmed" supported by the US National Library of Medicine and the more generic search-engine "Google Scholar".

The methodology followed by the research team for the selection of articles is presented schematically in Figure 1.
At a first stage, all published articles containing the word "leukemia" as part of their title, as a key-word or as a reference in their full text have been collected.

A set of criteria was adopted to narrow down the search results, excluding studies published more than 5 years prior to the review, studies that referred to subjects younger than 18 years (since the review referred to work-related risk factors) and studies whose full text was not available in English. All types of publications (i.e. prospective or retrospective studies, original articles, literature reviews, meta-analyses etc.) were considered at this stage.

The initial search recovered more than 10.000 articles (629 literature reviews) who were filtered by 2 different reviewers as regards their pertinence to the scopes of the study. The reviewers screened the abstracts of all collected articles and considered for further review only studies that referred to the potential effect of various risk factors (exposures) in the development of leukemia. The occupational or environmental nature of exposure was not examined at this stage. The review investigated information on the potential role of occupational risk factors regardless of the research type (toxicological, molecular, epidemiological study etc.) therefore no selection took place on the basis of specific study design. Nevertheless, with the exception of a number of articles who were further reviewed to elucidate potential points of interest, the overwhelming majority of clinical trials and laboratory studies were clearly non-relevant to the context of the review and were directly excluded, limiting the number of articles at the end of second phase to 278 .

For the final selection process the remaining articles were examined in detail by both reviewers. In cases of agreement, the corresponding articles were either excluded or included in the final list, while in cases of ambiguity there was further discussion among the 2 reviewers and a third reviewer who played the role of a referee, in order to reach consensus.

Articles considered eligible for inclusion were those that referred to specific categories of workers or exposure to occupational hazards and their effect on leukemia. The role of environmental exposures on leukemia was beyond the scope of this paper and all related studies were subsequently excluded.

A limited number of the reviewed articles on ionizing radiation and benzene did not refer specifically to occupational exposure, but their findings were considered significant for understanding the role of those hazards in occupational settings and were thus included in the final list. Finally, while leukemia in children was beyond the objectives of this study, the effect of parental occupational exposure on the risk of the disease among their offspring was considered work-related and therefore similar studies were also included in the final review. 


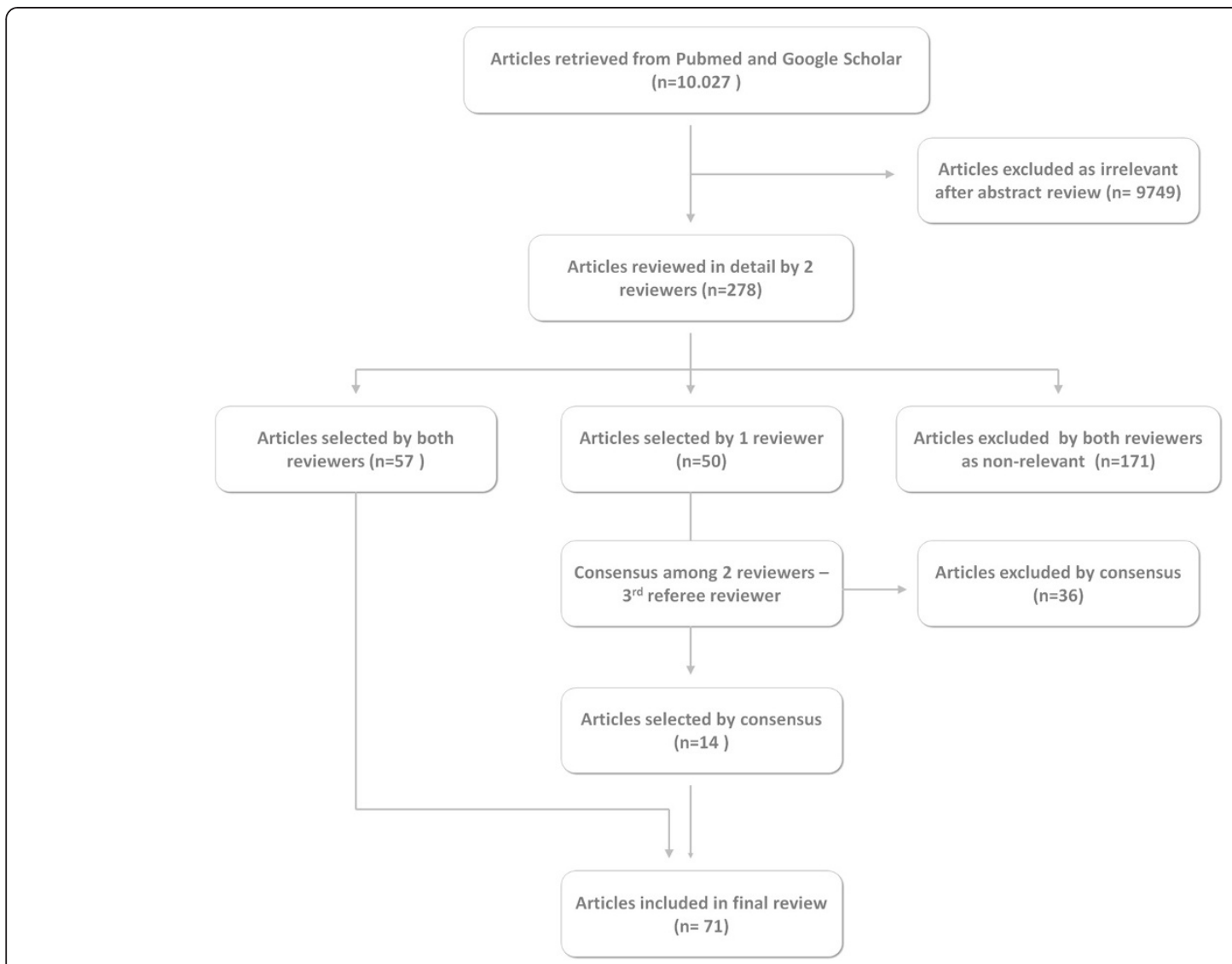

Figure 1 Article selection process for the review. The chart presented in this figure shows the overall process for the selection of articles from the initial electronic search to the final selection of the reviewed studies.

The 71 final studies, along with their main findings are presented in Tables 1, 2 and 3 classified according to the author, year, type of study and type of exposure. Table 1 presents the reviewed articles on physical hazards, Table 2 presents articles on chemical and biological hazards and Table 3 refers to others types of hazards and specific categories of workers.

\section{Main findings lonizing radiation}

As anticipated, the largest proportion of studies referred to ionizing radiation, which is to date the best documented risk factor for leukemia.

An update of Life Span Study findings has shown that exposure to ionizing radiation at doses as low as those usually recorded in occupational settings, leukemia incidence follows a quadratic dose response pattern, which peaks about 10 years following exposure and persists for decades $[6,9]$. Moreover, there is uncertainty on whether the proposed safety limits from the International Commission on Radiological Protection (ICRP) are appropriate, since revised LSS data show that the risk of leukemia remains increased even in groups with low cumulative exposure to radiation while most of the existing studies do not have sufficient statistical power to identify existing associations at such low exposure levels [98,99].

Ongoing observations on the impact of Chernobyl accident have shown that predictions based on LSS data present a high margin of error [100]. To date, a statistically significant increase of leukemia incidence has only been observed among the cleaning personnel that worked around the reactor site after the accident $[29,30]$. The study of Abramenko et al on specific genetic variants of CLL among this group of workers [28] implies a potential association among exposure to radiation and CLL which warrants further investigation given the lack of supporting evidence from previous studies.

As regards to a potential excess risk of leukemia among workers in the nuclear industry, the results of recent studies remain inconclusive. A number of studies among workers in nuclear-weapon industry have produced negative results [32-37] and despite sporadic positive findings, no significantly increased risk of leukemia has been established to date for nuclear power plant personnel $[38,98,99]$ and other categories of workers involved in other industrial applications of 
Table 1 Reviewed articles on physical hazards and leukemia

\begin{tabular}{|c|c|c|c|c|}
\hline Researcher & Year & Type of study & Exposure & Main findings \\
\hline \multicolumn{5}{|c|}{ A. lonizing radiation and leukemia } \\
\hline \multicolumn{5}{|c|}{ 1) Update of LSS study findings } \\
\hline Little et al. [6] & 2009 & Review & lonizing radiation & $\begin{array}{l}\text { Leukemia RR follows the pattern of LSS study for low dose (occupational) exposure - } \\
\text { Lower RR per dose unit for higher doses of radiation }\end{array}$ \\
\hline Richardson et al. [9] & 2009 & Cohort study & Ionizing radiation & $\begin{array}{l}\text { Exposure to }>5 \text { mGy of radiation is responsible for } 1 / 3 \text { of leukemia cases after } 5 \text { decades - } \\
\text { ERR/Gy follows a quadratic dose-response model for AML. ALL and CML mortality follow } \\
\text { a linear dose-response model. }\end{array}$ \\
\hline \multicolumn{5}{|c|}{ 2) Cleanup workers employed in Chernobyl nuclear incident } \\
\hline Rahu et al. [27] & 2006 & Cohort study & lonizing radiation & $\begin{array}{l}\text { No significant increase in leukemia incidence among workers (SIR } 1.53,95 \% \mathrm{Cl} 0.62-3.17) \text {. } \\
\text { A marginally significant increase has been observed among Latvian workers but it was } \\
\text { based on a small number of cases. }\end{array}$ \\
\hline Abramenko et al. [28] & 2008 & Cohort study & lonizing radiation & $\begin{array}{l}\text { Among a cohort of CLL patients, specific genetic polymorphisms where observed } \\
\text { more frequently among cleanup workers exposed to radiation following the } \\
\text { nuclear accident in Chernobyl than in non-exposed CLL patients }\end{array}$ \\
\hline Romanenko et al. [29,30] & 2008 & $\begin{array}{l}\text { Nested case- } \\
\text { control study }\end{array}$ & lonizing radiation & $\begin{array}{l}\text { Positive linear trend }(p=0.03) \text { between increasing exposure to radiation and leukemia risk. } \\
\text { The ERR/Gy for leukemia was } 3.44(95 \% \mathrm{Cl} 0.47-9.78) \text {. A linear dose - response relationship } \\
\text { has been shown for ALL and (surprisingly) for CLL. }\end{array}$ \\
\hline Kesminiene et al. [31] & 2008 & Case-control study & lonizing radiation & $\begin{array}{l}\text { A statistically significant association was shown (at } 90 \% \text { but not at } 95 \% \text { level) between AL and } \\
\text { employment as a cleanup worker in the surrounding area }(<30 \mathrm{~km}) \text { of Chernobyl accident } \\
\text { site (OR } 8.31,90 \% \mathrm{Cl} 1.17-122) \text {. }\end{array}$ \\
\hline \multicolumn{5}{|l|}{ 3) Workers in nuclear industry } \\
\hline Boice et al. [32] & 2006 & Cohort study & lonizing radiation & $\begin{array}{l}\text { No significant increase in leukemia mortality (SMR } 1.21,95 \% \mathrm{Cl} 0.69-1.97) \text { or increased leukemia } \\
\text { risk for the highly-exposed group (RR } 1.34,95 \% \mathrm{Cl} 0.73-2.45 \text { ) was shown among workers. }\end{array}$ \\
\hline Richardson et al. [33] & 2007 & Cohort study & $\begin{array}{l}\text { lonizing radiation } \\
\text { ( } \text { exposure to chemicals) }\end{array}$ & $\begin{array}{l}\text { A borderline significant increase of leukemia mortality was shown (at 90\% but not at } \\
95 \% \text { level) only for operators and manual workers (SMR 1.36, 90\% Cl 1.02-1.78) and } \\
\text { for workers employed }>30 \text { years (SMR 1.63, 90\% Cl 1.07-2.52). }\end{array}$ \\
\hline Richardson et al. [34] & 2007 & $\begin{array}{l}\text { Nested case- } \\
\text { control study }\end{array}$ & Ionizing radiation & $\begin{array}{l}\text { Assuming a 3-year time lag, no significantly increased ERR/10 mSv was shown for all leukemias } \\
(0.041,90 \% \mathrm{Cl}-0.001-0.116) \text {, for leukemias excluding } \mathrm{CLL}(0.077,90 \% \mathrm{Cl} 0.014-0.198) \\
\text { or for myeloid leukemia }(0.123,90 \% \mathrm{Cl} 0.021-0.354) \text {. }\end{array}$ \\
\hline Schubauer-Berigan et al. [35] & 2007 & $\begin{array}{l}\text { Nested case- } \\
\text { control study }\end{array}$ & Ionizing radiation & $\begin{array}{l}\text { A non-significant positive association between radiation dose and leukemia risk was shown } \\
\text { for doses } 10-100 \mathrm{mSv} \text {, with an estimated ERR/10 mSv of } 0.068(95 \% \mathrm{Cl}-0.029-0.24) \text {. }\end{array}$ \\
\hline Schubauer-Berigan et al. [36] & 2007 & $\begin{array}{l}\text { Nested case- } \\
\text { control study }\end{array}$ & lonizing radiation & $\begin{array}{l}\text { A non-significant positive association between radiation dose and CLL risk was shown for } \\
\text { doses } 10-100 \mathrm{mSv} \text {, with an estimated ERR/10 mSv of } 0.20(95 \% \mathrm{Cl}-0.035-0.96) \text {. }\end{array}$ \\
\hline Matanoski et al. [37] & 2008 & Cohort study & lonizing radiation & $\begin{array}{l}\text { No statistically significant increase of leukemia mortality (SMR 0.91, } 95 \% \mathrm{Cl} 0.56-1.39 \\
\text { and } 0.42,95 \% 0.11-1.07 \text { for exposure to }>5.0 \mathrm{mSv} \text { and }<5.0 \mathrm{mSv} \text { of radiation respectively) } \\
\text { was shown among workers }\end{array}$ \\
\hline Ashmore et al. [38] & 2010 & Review & lonizing radiation & $\begin{array}{l}\text { Previous study of IARC (2005) who found no statistically significant association between } \\
\text { leukemia and radiation exposure among workers in nuclear industry could be biased } \\
\text { due to inaccurate estimation of exposure. }\end{array}$ \\
\hline
\end{tabular}


Table 1 Reviewed articles on physical hazards and leukemia (Continued)

\begin{tabular}{|c|c|c|c|c|}
\hline \multicolumn{5}{|c|}{ 4) Medical applications of radiation } \\
\hline Lie et al. [39] & 2008 & Cohort study & lonizing radiation & $\begin{array}{l}\text { No significant increase in leukemia risk was found for the group nurses with the } \\
\text { longest ( }>30 \text { years) employment in posts exposed to radiation compared to the } \\
\text { group of non-exposed nurses (RR } 0.77,95 \% \text { Cl } 0.35-1.69 \text { ). }\end{array}$ \\
\hline Samerdokiene et al. [40] & 2009 & Cohort study & lonizing radiation & $\begin{array}{l}\text { No significant increase in leukemia incidence (SIR } 3.3,95 \% \mathrm{Cl} 0.68-9.63 \text { for men and } \\
2.67,95 \% \mathrm{Cl} 0.92-4.2 \text { for women) was shown among personnel employed in medical } \\
\text { applications of ionizing radiation. }\end{array}$ \\
\hline Ramos et al. [41] & 2008 & $\begin{array}{l}\text { Case-control study } \\
\text { (exposure assessment) }\end{array}$ & lonizing radiation & $\begin{array}{l}\text { The projected risk of leukemia cases/1000 person-years based on cumulative radiation exposure } \\
\text { among a group of interventional radiologists differed between } 2 \text { methods of exposure assessment } \\
\text { (1.07-3.98 according to the physical method compared to } 1.07-11.21 \text { for the biological method) } \\
\text { suggesting a potential improper use of personal dosimeters. }\end{array}$ \\
\hline Ramos et al. [42] & 2009 & $\begin{array}{l}\text { Molecular } \\
\text { epidemiological study }\end{array}$ & lonizing radiation & $\begin{array}{l}\text { The projected LAR of leukemia (cases/1000 person-years) among interventional radiologists } \\
\text { due to radiation exposure, was much higher according to biological methods of exposure } \\
\text { assessment (9.2) compared to physical methods (2.18). }\end{array}$ \\
\hline \multicolumn{5}{|c|}{ 5) Industrial applications of ionizing radiation } \\
\hline Ahn et al. [43] & 2008 & Cohort study & $\begin{array}{l}\text { lonizing radiation } \\
\text { (industrial applications) }\end{array}$ & $\begin{array}{l}\text { No statistically significant increase of leukemia SMR or SRR was shown among personnel } \\
\text { exposed to radiation (workers in medical applications, research laboratories, nuclear } \\
\text { facilities, non-destructive testing, military facilities etc.). }\end{array}$ \\
\hline \multicolumn{5}{|c|}{ 6) Extraction and use of uranium compounds } \\
\hline Storm [44] & 2006 & Cohort study & Depleted uranium & $\begin{array}{l}\text { No statistically significant increase of leukemia incidence was found among military personnel } \\
\text { exposed to depleted uranium used during military operations (SIR } 1.4,95 \% \mathrm{Cl} 0.4-3.5 \text { ). }\end{array}$ \\
\hline Mohner [45] & 2006 & Case-control study & $\begin{array}{l}\text { Uranium mining } \\
\text { (radionuclides) }\end{array}$ & $\begin{array}{l}\text { No significant increase of leukemia risk was found in the group with the highest cumulative } \\
\text { exposure to radon ( }>400 \mathrm{mSv} \text { ) compared to the low exposure group (OR 2.21, 90\% Cl 1.25-3.91). }\end{array}$ \\
\hline Mohner [46] & 2010 & Case-control study & $\begin{array}{l}\text { Uranium mining } \\
\text { (radionuclides) }\end{array}$ & $\begin{array}{l}\text { No significant increase of leukemia risk was found among the group of workers } \\
\text { with the highest (> } 200 \text { mSv) cumulative exposure (OR 1.33, 90\% Cl 0.82-2.14). }\end{array}$ \\
\hline \multicolumn{5}{|c|}{ B. Non-ionizing radiation (EMF) and leukemia } \\
\hline Roosli [47] & 2007 & Cohort-study & ELF EMF & $\begin{array}{l}\text { A significantly increased Hazard Ratio was shown for myeloid leukemia among the } \\
\text { workers with the highest exposure to ELF EMF (HR 4.74, 95\% Cl 1.04-21.6, } \mathrm{p}=0.035 \text { ). }\end{array}$ \\
\hline Kheifets [48] & 2008 & Meta-analysis & EMF & $\begin{array}{l}\text { A small but statistically significant increase in leukemia risk was found among the } \\
\text { exposed group (RR } 1.16,95 \% \mathrm{Cl} 1.11-1.22 \text { for all leukemias). }\end{array}$ \\
\hline
\end{tabular}


Table 2 Reviewed articles on chemical and biological hazards and leukemia

\begin{tabular}{|c|c|c|c|c|}
\hline Researcher & Year & Type of study & Exposure & Main findings \\
\hline \multicolumn{5}{|c|}{ 1) Exposure to benzene } \\
\hline Zhang [49] & 2007 & $\begin{array}{l}\text { Molecular } \\
\text { epidemiological study }\end{array}$ & Exposure to benzene & $\begin{array}{l}\text { A statistically significant increase \% of genetic aberrations commonly observed in } \\
\text { chemotherapy-related leukemias has been shown among workers exposed to } \\
\text { benzene compared to non-exposed controls. }\end{array}$ \\
\hline Richardson [50] & 2009 & Cohort study & Exposure to benzene & $\begin{array}{l}\text { The observed pattern of leukemia mortality among rubber-production workers exposed to } \\
\text { benzene, compared to the prediction of a TSCE statistical model suggests that benzene } \\
\text { plays a role to the kinetics of cancer cells rather than the initial malignant transformation. }\end{array}$ \\
\hline Rushton [51] & 2010 & Ecological study & Exposure to benzene & $\begin{array}{l}\text { The Attributable Fraction (AF) of population mortality from acute non-lymphocytic } \\
\text { leukemia related to occupational exposure to benzene was estimated at } \\
0.25 \% \text { ( } 95 \% \text { Cl 0.0-4.65). }\end{array}$ \\
\hline
\end{tabular}

\section{2) Exposure to organic solvents (incl. benzene)}

Costantini et al. [52]

2008 colycentric case-
control study

Organic solvents

Cocco et al. [53]

2010 Case-control study

Organic solvents

Lehman et al. [54]

2006 Cohort study

Organic solvents

$0.25 \%(95 \%$ Cl $0.0-4.65)$

\section{3) Exposure to Dioxins}

Atallah et al. [55]

Collins et al. [56]

2007 Case-report

2009 Cohort-study

Dioxins - Agent Orange

TCDD

\section{4) Exposure to chemical compounds used in the synthetic rubber industry}

Beall et al. [58] 2007 Cohort-study Solvents, aromatic amines

Cheng et al. [59]

2007 Cohort-study

Sathiakumar et al. [60,61]
$\mathrm{BD}$

BD, DMDTC and Styrene

Solvents, aromatic amines

$\mathrm{BD}$ and Styrene
A significant increase of $\mathrm{CLL}$ risk has been shown among the groups of workers with moderate - high exposure to Benzene (OR 1.8, 95\% Cl 0.9-3.9), and high exposure to Xylene (OR 1.9, 95\% Cl 0.8-4.5) and Toluene (OR 2.1, 95\% Cl 0.9-4.7).

A small but statistically significant increase of CLL risk (OR $1.3,95 \%$ Cl 1.1-1.6) was shown for workers ever exposed to organic solvents (exposure to any solvent or combined exposure of benzene with toluene, xylene or gasoline) compared to non-exposed.

No statistically significant increase in mortality from leukemia was found among exposed workers in footwear industry, compared with the general population (SMR 1.01, 95\% Cl 0.67-1.48).

A rare case of Acute Promyelocytic Leukemia (APL) in a former USAF pilot, who was involved in spraying Agent Orange during the Vietnam War, was reported.

No significant increase of leukemia mortality was shown among exposed workers (SMR 1.9, 95\% Cl 1.0- 3.2). No significant association was shown between leukemia mortality and cumulative exposure (ppb) to TCDD ( $\mathrm{p}=0.34$ ).
A positive association was shown between (all) leukemias, CML and CLL mortality and occupational exposure to BD. A positive association was also found between leukemia and exposure to Styrene or DMDTC, but in both cases there was also co-exposure to BD.

No increased leukemia incidence (SIR $0.68,95 \%$ Cl 0.14-1.98) or mortality (SMR 0.95 , $95 \% \mathrm{Cl} 0.31-2.23$ ) has been observed among exposed workers, compared to the general population.

A statistically significant association was shown between leukemia risk and exposure to $\mathrm{BD}$, for cumulative exposure in ppm-years (RR $3.84,95 \% \mathrm{Cl} 1.51-9.76)$, frequency of exposure (RR 4.26, 95\% Cl 1.62-11.21) and average exposure in ppm (RR 3.93, $95 \%$ Cl 1.5-10.32).

In contrast to the results observed among men workers, no statistically significant association was found between exposure of women workers to BD and mortality from leukemia (SMR 0.78, 95\% Cl 0.38-1.44). 
Table 2 Reviewed articles on chemical and biological hazards and leukemia (Continued)

\begin{tabular}{llll}
\hline $\begin{array}{l}\text { 5) Exposure to Formaldehyde } \\
\text { Beane Freeman [62] }\end{array} 2009$ & Cohort-study & Formaldehyde \\
Hauptmann [63] & 2009 & Case-control study & Formaldehyde \\
Zhang [64] & 2010 & $\begin{array}{l}\text { Molecular } \\
\text { epidemiological study }\end{array}$ & Formaldehyde \\
Speit [65] & 2010 & Letter to the editor & Formaldehyde
\end{tabular}

\begin{tabular}{|c|c|c|c|}
\hline \multicolumn{4}{|c|}{ 6) Exposure to Lead } \\
\hline Lam [66] & 2007 & Cohort study & $\begin{array}{l}\text { Occupational } \\
\text { exposure to lead }\end{array}$ \\
\hline
\end{tabular}

\section{7) Exposure to different types of pesticides, herbicides and insecticides}

$\begin{array}{llll}\text { Mahajan [67] } & 2006 \quad \text { Cohort study - (AHS) } & \begin{array}{l}\text { Organophosphate } \\ \text { pesticide - Fonofos }\end{array} \\ \text { Mahajan [68] } & 2006 \quad \text { Cohort study - (AHS) } & \begin{array}{l}\text { Organophosphate } \\ \text { pesticide - Phorate }\end{array} \\ \text { Miligi [69] } & 2006 \quad \text { Case-control study } & \begin{array}{l}\text { Different groups of } \\ \text { pesticides }\end{array}\end{array}$

$\begin{array}{ll}2007 \text { Cohort study } & \text { Arsenate pesticides, Atrazine, } \\ & \text { Dichlorvos, Captafol, Amitrol, } \\ & \text { Lindane, DDT }\end{array}$

2007 Cohort study - (AHS) Organochlorine insecticides $\begin{array}{ll}\text { (Aldrin, Chlordane, DDT, Dieldrin, } & \text { previous use of any of the Organochlorine pesticides (RR 2.0, 95\% Cl 1.0-4.1), Lindane } \\ \text { Heptachlor, Lindane, Toxaphene) } & \text { (RR 2.0, 95\% Cl 1.1-3.5) or Heptachlor (RR 2.1, 95\% Cl 1.1-3.9). }\end{array}$

van Bemmel [72]

2008 Cohort study - (AHS)

Chrisman Jde [73]

2009 Ecological study

All pesticides

Delancey [74]

2009 Cohort study - (AHS)

Herbicide Metribuzin

A non-significant increase in mortality from (all) leukemias (RR 1.42, 95\% Cl 0.92- 2.18) and myeloid leukemia (RR 1.78, 95\% 0.87- 3.64) was shown in the group with the highest exposure (> 4ppm) compared to the group with the lowest exposure.

A statistically significant association between mortality from myeloid leukemia and increasing years of employment $(\mathrm{p}=0.02)$ or maximum exposure to formaldehyde $(\mathrm{p}=0.036)$ was shown among embalmers.

A statistically significant decrease of cell-lines, reduced activity of the CFU-GMs and increase of leukemia-related genetic aberrations has been shown among workers xposed to formaldehyde compared to non-exposed controls.

A number of methodological issues call into question the reliability of the findings of the study of Zhang et al, on in-vitro evidence of leukemia-specific chromosomal changes in workers exposed to formaldehyde.

A non-significant increase of CML incidence was shown (SIR 1.75, 95\% Cl 0.02- 9.71) among the cohort of workers exposed to lead (metal constructions, metal processing industry, foundries, manufacture of batteries and electronics, glass production).

A statistically significant increase of leukemia risk was found among pesticide applicators with the highest exposure (based on duration and intensity of exposure) compared to the non-exposed (RR 2.67, 95\% Cl 1.06-6.70).

The small number of recorded cases of leukemia among exposed workers did not low for any reliable conclusions.

No significant association with leukemia risk was shown for exposure to fungicides (OR 1.0, 95\% Cl 0.7 -1.3), herbicides (OR 1.4, 95\% Cl 0.8-2.3), insecticides (OR 1.0, 95\% C $0.7-1.4$ ), molluscicides (OR $0.9,95 \% \mathrm{Cl} 0.3-2.5$ ) or rodenticides (OR $0.4,95 \% \mathrm{Cl} 0.1-1.2$ ).

A significant increase of leukemia incidence (SIR $2.33,95 \%$ Cl 1.32- 4.10) was found among the group of gardeners with high exposure to pesticides, previous to the 1960 restriction of the use of potentially carcinogenic substances. (RR 2.0, 95\% Cl 1.1-3.5) or Heptachlor (RR 2.1, 95\% Cl 1.1-3.9).

No statistically significant increase of leukemia risk was shown for workers exposed EPTC (RR 1.31, 95\% Cl 0.75-2.28) compared to the non-exposed.

A statistically significant increase of leukemia mortality was observed in areas with increased per capita use of pesticides (MRR 1.6, 95\% Cl 1.55-1.66 and 1.93, 95\% Cl 1.87-2.0 for the $1^{\text {st }}$ quartile of pesticide use, compared to the $2^{\text {nd }}$ and $3^{\text {rd }}$ quartile respectively).

A statistically non-significant increase of leukemia risk was shown among the group of pesticide applicators with the highest cumulative exposure to Metribuzin (RR 2.42, 95\% Cl 0.82-7.19, $\mathrm{p}=0.08$ ). 
Table 2 Reviewed articles on chemical and biological hazards and leukemia (Continued)

\begin{tabular}{|c|c|c|c|c|}
\hline Orsi [75] & 2009 & Case-control study & $\begin{array}{l}\text { Organochlorine insecticides, } \\
\text { Phenoxy - herbicides, Triazine- } \\
\text { containing herbicides }\end{array}$ & $\begin{array}{l}\text { A significant association was shown between the risk of hairy cell leukemia (HCL) } \\
\text { and exposure to Organochlorine insecticides (OR 4.9, 95\% Cl 1.1-21.2), Phenoxy-herbicides } \\
\text { (OR 4.1, 95\% Cl 1.1-15.5) and Triazine-containing herbicides (OR 5.1, 95\% Cl 1.4-19.3). }\end{array}$ \\
\hline Rusiecki [76] & 2009 & Cohort study - (AHS) & Exposure to Permethrin & $\begin{array}{l}\text { No significant association was shown between exposure to Permethrin and leukemia risk } \\
\text { among workers (RR } 1.74,95 \% \mathrm{Cl} 0.83-3.64 \text { and } 1.34,95 \% \mathrm{Cl} 0.61-2.92 \text { for workers with the } \\
\text { longest duration of exposure or the highest cumulative exposure respectively). }\end{array}$ \\
\hline \multicolumn{5}{|c|}{ 8) Combined chemical and biological hazards in agriculture } \\
\hline Bassil [77] & 2007 & Literature review & $\begin{array}{l}\text { Combined exposure to pesticides, } \\
\text { insecticides and work with livestock }\end{array}$ & $\begin{array}{l}6 \text { cohort studies and } 8 \text { case-control studies have shown a statistically significant } \\
\text { association between pesticide exposure and leukemia risk, and } 2 \text { cohort studies } \\
\text { have shown an association between leukemia risk and work with livestock. }\end{array}$ \\
\hline \multicolumn{5}{|c|}{ 9) Biological hazards in agriculture and food industry } \\
\hline Moore [78] & 2007 & Case-control study (multicentric) & $\begin{array}{l}\text { Occupational exposure } \\
\text { to meat products }\end{array}$ & $\begin{array}{l}\text { A statistically significant association was found between CLL risk and occupational exposure } \\
\text { to meat products, for workers with exposure> } 16 \text { years to cattle and poultry meat } \\
\text { (OR 2.51,95\% Cl } 1.12-5.66 \text { and } 2.06,95 \% \mathrm{Cl} 1.17-3.63 \text { respectively). }\end{array}$ \\
\hline Johnson [79] & 2010 & Cohort study & $\begin{array}{l}\text { Occupational exposure } \\
\text { to meat products }\end{array}$ & $\begin{array}{l}\text { A statistically significant increase of lymphatic leukemia mortality was shown among men } \\
\text { workers in slaughterhouses and poultry meat processing plants (SMR } 5.9,95 \% \mathrm{Cl} \\
\text { 1.6-15.2). No similar increase was found among female workers. }\end{array}$ \\
\hline Johnson [80] & 2010 & Cohort study & $\begin{array}{l}\text { Occupational exposure } \\
\text { to meat products }\end{array}$ & $\begin{array}{l}\text { A statistically significant increase of lymphatic leukemia proportional mortality was } \\
\text { observed only among non-white women workers in slaughterhouses and poultry } \\
\text { meat processing plants (PMR 6.4, 95\% Cl 1.3-31.1). }\end{array}$ \\
\hline
\end{tabular}


ionizing radiation (medicine, research laboratories, nondestructive testing etc.) $[39,40,43]$.

Exposure to minimal doses of radiation during the mining and processing of uranium has not been associated with a significantly increased risk of leukemia among exposed workers $[45,46]$. Moreover, despite existing weaknesses in their methodological design and statistical power [101], recent studies did not record any statistically significant increase in leukemia risk among military personnel exposed to depleted uranium products during military operations $[44,102]$.

\section{Non-ionizing radiation (EMF)}

Occupational exposure to electromagnetic fields (EMF) constitutes an area of ongoing scientific debate over the recent years, mainly because of the rising public health concern regarding EMF. There has been high inconsistency among the results of previous studies, but the research group of the International Commission on Non-Ionizing Radiation Protection (ICNIRP) concluded that existing literature on EMF exposure converges on the existence of a small but statistically significant increase in leukemia risk among occupationally exposed groups [47]. These findings were further supported by more recent studies, which identified a small but statistically significant excess risk of leukemia among workers highly exposed to extremely low frequency electromagnetic fields (ELF EMF) $[47,48]$.

\section{Benzene}

Among various chemical exposures in the workplace, Benzene is a well-documented risk factor for leukemia. As regards the potential toxicity of Benzene at cellular level, Zhang et al have observed in vitro a significantly higher number of genetic lesions associated with chemotherapy-related leukemia among Benzene-exposed workers [49], while Richardson et al have proposed a model of two-stage clonal expansion (TSCE) of cancer cells where Benzene acts as a promoter (rather than an initiator) affecting the kinetics of initiated blood cells [50]. A recent study in Great Britain estimated that due to the widespread use of benzene-containing compounds in various applications, occupational exposure to Benzene is responsible for about $0.19 \%$ of the overall incidence of non-lymphocytic leukemia in men and $0.34 \%$ in women [51], while a similar study in Korea has shown that Benzene constitutes at population-level a more significant occupational risk factor for leukemia than ionizing radiation [103].

\section{Other organic solvents}

Most epidemiological studies on occupational exposure to organic solvents other from Benzene have not investigated exposure to each compound separately, therefore the effect of co-exposure to benzene in the observed excess risk of leukemia could not be ruled out [52,53]. In a single study where exposure to organic solvents (Toluene, Hexane, Acetone, and Methyl-ethyl-ketone) was investigated independently from Benzene, no significantly increased risk of leukemia has been observed among the exposed workers [54].

\section{Butadiene and dimethyl-dithio-carbamate}

An interesting finding that warrants further research has occurred from a series of studies conducted on workers in the synthetic rubber industry, where a statistically significant excess risk of CML and CLL following a dose-response relationship was shown among workers exposed to 1.3-butadiene (BD) and dimethyl-dithio-carbamate (DMDTC) [57,59]. Interestingly, a similar finding was not observed among female workers, although their cumulative exposure to the specific compounds had been much smaller than men $[60,61]$.

\section{Formaldehyde}

Although formaldehyde has been classified by the International Agency for Research on Cancer (IARC) in Group 1 "Carcinogenic to Humans" as regards to other types of malignancies [104,105], a potential role in the development of leukemia remains an area of ongoing scientific controversy, as epidemiological findings remain inconclusive $[62,106]$ and no plausible theory has been proposed to date to explain a toxic effect on progenitors of blood cells [107]. In 2 recent Meta-analyzes of relevant studies however, a statistically significant excess risk of leukemia has been observed among those occupationally exposed to formaldehyde $[108,109]$, while despite the criticism over its methodological weaknesses [110] an additional study has shown a statistically significant dose-response association between exposure to formaldehyde and mortality from myeloid leukemia among embalmers [63]. As regards the elucidation of the potential role of formaldehyde in the pathogenesis of leukemia, Zhang et al have reported in vitro evidence of formaldehyde myelotoxicity and identification of leukemia-characteristic genetic lesions among the myeloid lineage of formaldehyde-exposed workers [64], although there have been major objections to their findings by a different group of researchers [65]. Overall, while existing data could provide some explanation for the potential toxicity of Formaldehyde in remote target-organs and the negative findings in experimental animals, it seems that there is still a long way when it comes to document a role of Formaldehyde in the pathogenesis of leukemia [111].

\section{Lead}

The toxic effects of exposure to Lead on bone marrow have long been recognized. However, the cohort study of Lam et al. among lead-exposed workers (metal 
construction, metal processing, battery manufacture, glass production and electronics' industry) has not detected any significant increase of leukemia risk [66].

\section{Pesticides}

Pesticides are a class of chemicals long suspected for carcinogenicity, and a number of different studies have been conducted over the last decade to investigate the toxic effect of specific classes of pesticides or compounds and their potential role in the development of leukemia. With the exception of an Italian case-control study which has shown no significant association between leukemia risk and exposure to the main categories of pesticides [69], a number of studies have recorded statistically significant excess risk of leukemia among agricultural workers exposed to pesticides in general [73,77], or specific categories of pesticides such as Phenoxy-herbicides, Triazine herbicides, Arsenic-containing pesticides, Atrazine, Lindane, Dichloro Diphenyl Trichloroethane (DDT), etc. [70,75]. A positive association was also shown between leukemia and exposure to organophosphate pesticide Fonofos [67], while for workers exposed to thio-carbamate herbicide EPTC [72], Organochlorine insecticides [71], Metribuzin [74] and Permethrin [76] no statistically significant excess leukemia risk was found.

\section{Infectious agents - contact with animals}

The potential association of leukemia with exposure to infectious agents is not a new theory but there seems to be a renewed interest as regards to the epidemiological investigation of this hypothesis during the last decade. A number of epidemiological studies have investigated the existing risk of leukemia among specific occupational groups in livestock farming, food production and processing where a higher theoretical risk of exposure to biological agents from the animal population exists [112-114]. The findings of those studies support the above hypothesis, as a statistically significant increase of leukemia risk was shown for workers in livestock farming $[77,115]$, and a number of occupations i.e. workers in slaughterhouses, butchers, cooks, etc. involved in the processing of animal meat products [78-80].

\section{Specific occupational groups at risk}

Of the published epidemiological studies that investigated potential associations of leukemia with specific occupational groups over the last 5 years, a statistically significant increase in mortality from leukemia has been recorded among the personnel of chemical laboratories [84] and oil processing facilities [86], while no increased risk for leukemia was shown for firefighters [85] and tannery workers [88]. In 2 epidemiological studies conducted among healthcare personnel, no increased risk for leukemia was shown for the group of nurses [81] and neurosurgeons [83] while the findings of a third study which has shown increased mortality from CLL among nurses may be strongly affected by overdiagnosis of the disease due to the increased health awareness of the specific group [82]. Furthermore, a number of ecological-design studies have recorded a statistically significant excess risk of leukemia among specific categories of workers which include women (other than nurses) working in the healthcare sector [89], workers whose tasks involve exposure to Polychlorinated Biphenyls (PCBs) and printing inks [91], workers exposed to benzene or pesticides or working near high voltage lines [92], workers in plastic production, cleaning and construction work [93], and several categories of workers in the agricultural sector i.e. fruit and vegetable growers, nursery workers, farmers, florists etc. [93].

\section{Parental occupational exposure and childhood leukemia}

With regards to the potential association of childhood leukemia with parental occupational exposure, paternal exposure to pesticides and herbicides has not been associated with increased risk [94]. The study of Pearce et al has shown a potential association of paternal exposure to EMF with childhood leukemia, but their findings could be the effect of co-exposure to ionizing radiation [95]. Finally, paternal exposure to carcinogens [97] and maternal exposure to solvents [96] especially during pregnancy and after birth have been associated with increased risk of childhood leukemia among their offspring.

\section{Conclusions}

The studies included in this literature review, present the current scientific knowledge on the potential effect of work-related hazards in the pathogenesis of leukemia. It must be noted, a number of those studies suffer from methodological weaknesses which in certain cases constitute their findings precarious.

Given the relatively low incidence and the long natural history of the disease, the investigation of a potential effect of an occupational exposure on leukemia requires largescale cohort studies with long follow-up period to acquire the necessary statistical strength, which usually exceeds the resources or the size of the study cohort. Even when the above conditions are met, the statistical strength of a study can be significantly reduced if the study protocol for the assessment of exposure contains flaws. The establishment of the role of an occupational hazard in the development of leukemia assumes the demonstration of both a statistically significant impact on leukemia incidence or mortality between the exposed and non-exposed as well as a dose-response effect for different levels of exposure. In cases where available data on personal exposure is insufficient, as appears to be the case for a number of the cohort studies included in this review, an over- or under- 
Table 3 Reviewed articles on other hazards and leukemia

\begin{tabular}{l} 
Researcher Year Type of study Exposure \\
\hline A) Occupational exposure and risk of leukemia among different categories of workers \\
\hline 1) Healthcare workers
\end{tabular}

Dimich-Ward [81] 2007 Cohort study Working as a nurse

Main findings

\begin{tabular}{|c|c|c|c|c|}
\hline Abel [82] & 2009 & $\begin{array}{l}\text { Cohort study } \\
\text { (Nurses' Health Study) }\end{array}$ & Working as a nurse & $\begin{array}{l}\text { A statistically significant increase of CLL incidence was found among nurses } \\
\text { compared to the general population (SIR } 1.35,95 \% \mathrm{Cl} 1.17-1.54 \text { ). }\end{array}$ \\
\hline Lollis [83] & 2010 & Cohort study & $\begin{array}{l}\text { Exposure to different health } \\
\text { hazards of operating theaters }\end{array}$ & $\begin{array}{l}\text { No statistically significant increase in mortality from leukemia was observed } \\
\text { among neurosurgeons compared to the general population (SMR 1.2, 95\% Cl 0.75-1.9). }\end{array}$ \\
\hline
\end{tabular}

\section{2) Workers in chemical laboratories}

Kubale [84] 2008 Cohort study

Radionuclides, benzene and other hazards in Leukemia mortality of workers did not differ significantly from the general population

the laboratories of nuclear research facilities (SMR 0.78, 95\% Cl 0.45-1.25). A significant positive association was shown between

leukemia risk and duration of employment for those employed $>20$ years (SRR was

$9.51,95 \% \mathrm{Cl} 1.67-54.17$ and $11.44,95 \% \mathrm{Cl} 1.88-69.54$, for an estimated 2- or 5-year time-lag of the disease respectively).

\section{3) Firefighters}

Bates [85] 2007 Case-control study Inhalation of toxic combustion products The risk of developing leukemia did not differ significantly between firefighters and the non-exposed group (OR 1.22, 95\% Cl 0.99-1.49).

\section{4) Workers in petroleum processing facilities}

Byproducts of petroleum distillation and processing

Gazdek [87] 2007 Ecological study Emissions from oil and gas processing plants

A statistically significant increase of mortality from acute (non-lymphoblastic) leukemia was observed among workers in the chemical department (SMR 1.81, 95\% Cl 1.06-2.90), but no association with duration of employment or specific job posts was identified. Statistically significant geographic variation of acute myeloid leukemia incidence was observed among populations of different regions, depending on their proximity to oil- and gas-processing plants.

\section{5) Tannery workers}

2006 Cohort study $\quad$ Chemicals used in leather processing

No significant increase of myeloid leukemia mortality was found among tannery workers exposed to chemicals used for leather processing (SMR was 2.08, 90\% Cl 0.82-4.37 for men and 5.99, 90\% Cl 1.06-18.87 for women).

\section{6) Different occupational categories}

$\begin{array}{ll}2007 \text { Firth [89] Ecological study } & \begin{array}{l}\text { Different occupational exposures } \\ \text { of women }\end{array}\end{array}$

Hoffmann [90] 2008 Case-control study lonizing radiation, pesticides and EMF

Richardson [91] 2008 Case-control study Different occupational exposures
A significant increase of leukemia proportional mortality was found among women employed in the healthcare sector (PMR 1.52, 95\% Cl 1.08- 2.09) but not for nurses (PMR 1.42, 95\% Cl 0.96-2.01).

$15 \%$ of men (16\% of women) participants reported occupational exposure to pesticides $4 \%$ ( $8 \%$ women) reported exposure to ionizing radiation (for $>1$ year) and $64 \%$ of participants reported having lived sometime in their life in the proximity $(<20 \mathrm{~km})$ of a nuclear plant.

A statistically significant increase of CLL risk was shown among workers exposed to polychlorinated biphenyls (PCBs) (OR 1.48, 95\% Cl 1.02-2.16) and printing inks (OR 1.89, $95 \%$ Cl 1.21-2.96). 
Table 3 Reviewed articles on other hazards and leukemia (Continued)

Kaufman [92] 2009 Case-control study Benzene, pesticides, ionizing radiation and EMF

McLean [93]

2009 Case-control study

Different occupational exposures

A statistically significant increase of myeloid leukemia was shown among workers exposed to Benzene (OR 3.9, 95\% Cl 1.3- 11), other non-specified solvents (OR 2.1, 95\% Cl 1.1- 4.9), pesticides (OR 3.8, 95\% Cl 2.1-7.1) and EMF (OR 4.3, 95\% Cl 1.3-15).

A statistically significant increase of leukemia risk was found among workers employed in fruit and vegetable cultivation (OR 2.62,95\% Cl 1.51 - 4.55) and in nurseries (OR 7.51,

$95 \% \mathrm{Cl} 1.85-30.38$ ), machine operators in plastic production facilities (OR $3.76,95 \% \mathrm{Cl} 1.08-13.08$ ), tailors and dressmakers (OR for CLL 7.01, 95\% Cl 1.78-27.68), cleaners (OR for CLL 2.04, 95\% Cl

1.00-4.14) and construction workers (OR for CLL 4.03, 95\% Cl 1.30-12.53).

\section{B) Occupational exposure and risk of leukemia among the offspring of different categories of workers}

Pearce [94] 2006 Case-control study Pesticides and herbicides

Pearce [95]

2007 Case-control study

EMF, ionizing radiation

McKinney [96]

2008 Case-control study

Solvents, degreasing and cleaning agents

Perez-Saldivar [97] 2008 Case-control study

Carcinogenic compounds
Paternal occupational exposure to pesticides and herbicides did not appear to be associated with a higher risk of leukemia among their offspring (OR 0.55, 95\% Cl 0.26-1.16 and 1.15, 95\% Cl $0.61-2.17$ for children living in urban and rural areas respectively).

A statistically significant association was shown between the risk of childhood leukemia and previous paternal occupational exposure to EMF (and ionizing radiation) (OR 1.31, $95 \%$ Cl 1.02-1.69), especially among the offspring of electricians (OR $1.59,95 \% \mathrm{Cl} 1.12-2.26$ ).

A statistically significant association was found among acute lymphoblastic leukemia risk in children and maternal exposure to solvents, degreasing and cleaning agents, during the period of pregnancy (OR 2.7, 95\% Cl 1.6- 4.6) and postpartum (OR 1.9, 95\% Cl 1.1-3.3).

A statistically significant association was found between childhood leukemia risk and previous paternal exposure to carcinogens (OR 2.06, 95\% Cl 1.24-3.42). 
estimation of exposure in certain groups of workers may have led to non-differential misclassification, reducing their statistical strength below the point where a weak (but existing) statistical association could be identified.

Case-control studies were susceptible to even more types of error, since apart from misclassification bias as regards the exposure (or the diagnosis, especially in studies based on historical records) major types of systematic error could undermine the reliability of their findings. Most casecontrol studies took place long after exposure, and the possibility of recall-bias, leading to an erroneous estimation of exposure, is high. Recall-bias could introduce a major error in the results of the studies especially when it is unevenly distributed among cases and controls (e.g. studies where exposure assessment was based on indirect information given by close relatives of colleagues of leukemia patients). Furthermore, some of the studies may have been affected by selection bias either as a result of a change in the composition of their reference population (e.g. migration of leukemia patients for diagnostic or therapeutic purposes outside a country may have led to over-representation of lower socio-economic classes and specific occupational groups among cases) or the over-representation of protective health behaviors among controls due to the followed sampling methodology.

A major concern with regards to published literature reviews and meta-analyses was the low comparability among the studies they were based on, as their different methodological design, analytical methods and presentation of results, made even simple comparisons among their findings difficult, let alone further processing of the data for the purpose of meta-analysis. This has affected some of the findings presented in this review, as some of the metaanalyses, as admitted by their own authors, could have reached completely different results if some of the largescale studies which have been excluded from the analysis had met the criteria for inclusion.

Overall, during the reference period of this study there have not been any radical changes in the existing scientific knowledge as regards the role of work-related hazards in the pathogenesis of leukemia.

The findings of the reviewed articles confirm or fail to negate previous scientific observations on the effect of known risk factors, and there is adequate consistency among researchers as to the causal association between ionizing radiation or benzene and leukemia. Nevertheless, the results of different studies remain contradictory as regards the effect of radiation on different occupational groups, and the impact on leukemia risk at different exposure levels. Regarding exposure to benzene as a single compound, or as part of mixtures of solvents, the findings are consistent as to a positive association with the risk of leukemia among exposed workers, yet no agreement exists on its exact role on the development of the disease.
The epidemiological findings of different studies remain contradictory on the role of most of the remaining suggested risk factors. The positive associations shown by a number of studies as regards occupational exposure to EMF, BD or infectious agents warrant further research in the future, as different researchers fail to reproduce their statistically significant results. In the case of formaldehyde apart from the inconsistency of epidemiological findings as regards the effect on leukemia among exposed workers, there is also a scientific debate as to the plausibility of a theoretical model of action explaining its role in the development of the disease. Finally, the reviewed studies on occupational exposure to a number of plant protection products (pesticides, herbicides, insecticides) indicate a large heterogeneity among this group of chemical compounds as regards their potential effect on the risk of leukemia, and could provide an adequate explanation for the low reproducibility of findings among different researchers when characterization of exposure is not clearly defined.

The number of collected articles (especially cohort studies) investigating the potential association between different occupational hazards and leukemia, published during the previous years, indicates a growing scientific interest in the specific field in an attempt to improve our understanding on the causal factors of the disease. Nevertheless, based on the reviewed studies the potential effect of those hazards on the observed incidence and mortality of leukemia, if existing, is expected to be so subtle that could easily go unnoticed by small- or medium-scale epidemiological studies. Therefore, even negative results should be evaluated with caution, pending additional information from ongoing research.

Technology has provided new tools to researchers during the last decades for in vitro investigation of diseases like leukemia at cellular or molecular level. This will be perhaps the key to unraveling the pathophysiological mechanisms of this complex disease and acquire new insight on the actual causes of leukemia in the future, since epidemiology appears to have reached its limits as regards to introducing new knowledge in this field.

It is possible that, for diseases such as leukemia, the day when classical epidemiology will give its place to environmental genomics or proteomics to investigate complex interactions between occupational or environmental exposures and their effect at genetic or molecular level, is not far from today.

\section{Abbreviations}

RR: Relative risk; ERR: Excess relative risk; Gy: Gray; LSS: Life span study; AML: Acute myeloid leukemia; CML: Chronic myelogenous leukemia; ALL: Acute lymphoblastic leukemia; CLL: Chronic lymphocytic leukemia; AL: Acute leukemia; PEL: Permissible exposure limit; ppm: Parts per million; TWA: Time weighted average; ICRP: International Commission on Radiological Protection; EMF: Electromagnetic fields; ELF EMF: Extremely low frequency electromagnetic fields; ICNIRP: International Commission on 
Non-lonizing Radiation Protection; TSCE: Two-stage clonal expansion; BD: 1.3butadiene; DMDTC: Dimethyl-dithio-carbamate; IARC: International Agency for Research on Cancer; DDT: Dichloro Diphenyl Trichloroethane; EPTC: S-ethyl-N,N-dipropylthiocarbamate; PCB: Polychlorinated Biphenyls; SIR: Standardized Incidence Ratio; OR: Odds Ratio; mSv: Millisievert; LAR: Life-time Attributable Risk; AF: Attributable fraction; APL: Acute Promyelocytic Leukemia; USAF: United States Air Force; TCDD: Tetrachloro-dibenzo-dioxin; CFU-GM: Colony Forming Unit-Granulocyte/Macrophage; AHS: Agricultural Health Study.

\section{Competing interests}

The authors declare that they have no competing interests.

\section{Authors' contributions}

$I P, G D, V M, E R$, and $A L$ have made substantial contributions to the conception and design of the review, acquisition of the review data and have been involved in drafting and revising the manuscript. All authors have read and approved the final manuscript.

\section{Author details}

'Department of Hygiene, Epidemiology and Medical Statistics, University of Athens, Medical School, 75 Mikras Asias 115 27, Goudi, Athens, Greece. ${ }^{2}$ Occupational \& Industrial Hygiene Department, National School of Public Health, 96 Alexandras Av. 11521, Athens, Greece.

Received: 26 October 2012 Accepted: 6 May 2013

Published: 22 May 2013

\section{References}

1. Bozzone DM: The biology of cancer: Leukemia. New York: Infobase Publishing; 2009.

2. Boyle P, Levin B (Eds): World Cancer Report 2008. Lyon: International Agency for Research on Cancer (IARC); 2008.

3. Mughal TI, Goldman JM, Mughal ST: Understanding Leukemias, Lymphomas and Myelomas. London: Taylor \& Francis; 2006.

4. Committee to Assess Health Risks from Exposure to Low Levels of lonizing Radiation, National Research Council: Health Risks from exposure to low levels of ionizing radiation: BEIR VII Phase 2. Washington D.C.: The National Academies Press; 2006.

5. Kato H, Schull WJ: Studies of the mortality of A-bomb survivors. 7. Mortality, 1950-1978: Part I. Cancer mortality. Radiat Res 1982, 90:395-432.

6. Little MP: Cancer and non-cancer effects in Japanese atomic bomb survivors. J Radiol Prot 2009, 29:A43-A59.

7. Preston DL, Pierce DA, Shimizu Y, Cullings HM, Fujita S, Funamoto S, Kodama K: Effect of recent changes in atomic bomb survivor dosimetry on cancer mortality risk estimates. Radiat Res 2004, 162:377-389.

8. Preston DL, Kusumi S, Tomonaga M, Izumi S, Ron E, Kuramoto A, Kamada N, Dohy H, Matsuo T, Matsui T, et al: Cancer incidence in atomic bomb survivors. Part III. Leukemia, lymphoma and multiple myeloma, 19501987. Radiat Res 1994, 137:S68-S97.

9. Richardson D, Sugiyama H, Nishi N, Sakata R, Shimizu Y, Grant EJ, Soda M, Hsu WL, Suyama A, Kodama K, Kasagi F: lonizing radiation and leukemia mortality among Japanese Atomic Bomb Survivors, 1950-2000. Radiat Res 2009, 172:368-382.

10. Noshchenko AG, Zamostyan PV, Bondar OY, Drozdova VD: Radiationinduced leukemia risk among those aged $0-20$ at the time of the Chernobyl accident: a case-control study in the Ukraine. Int J Cancer 2002, 99:609-618.

11. Austin $H$, Delzell $E$, Cole P: Benzene and leukemia. A review of the literature and a risk assessment. Am J Epidemiol 1988, 127:419-439

12. Pubchem Compound Database: Benzene - Compound Summary CID 241: http://pubchem.ncbi.nlm.nih.gov/summary/summary.cgi?cid=241\&loc=ec_rcs.

13. Moen BE, Steinsvag K, Braveit M: What do we know about chemical hazards in offshore work? Tidsskr Nor Laegeforen 2004, 124:2627-2629.

14. Hayes RB, Songnian Y, Dosemeci M, Linet M: Benzene and lymphohematopoietic malignancies in humans. Am J Ind Med 2001, 40:117-126

15. Rinsky RA, Smith AB, Hornung R, Filloon TG, Young RJ, Okun AH, Landrigan PJ: Benzene and leukemia. An epidemiologic risk assessment. N Engl J Med 1987, 316:1044-1050.
16. Khalade A, Jaakkola MS, Pukkala E, Jaakkola JJ: Exposure to benzene at work and the risk of leukemia: a systematic review and meta-analysis. Environ Health 2010, 9:31.

17. Lamm SH, Engel A, Joshi KP, Byrd DM 3rd, Chen R: Chronic myelogenous leukemia and benzene exposure: a systematic review and meta-analysis of the case-control literature. Chem Biol Interact 2009, 182:93-97.

18. Rowley JD, Golomb HM, Vardiman J: Acute leukemia after treatment of lymphoma. N Engl J Med 1977, 297:1013.

19. Sekeres MA, Kalaycio ME, Bolwell BJ (Eds): Clinical Malignant Hematology. New York: McGraw-Hill; 2007.

20. Connor TH, McDiarmid MA: Preventing occupational exposures to antineoplastic drugs in health care settings. CA Cancer J Clin 2006, 56:354-365.

21. Mason HJ, Morton J, Garfitt SJ, labal S, Jones K: Cytotoxic drug contamination on the outside of vials delivered to a hospital pharmacy. Ann Occup Hyg 2003, 47:681-685.

22. Preventing Occupational Exposures to Antineoplastic and Other Hazardous Drugs in Health Care Settings. Cincinnati: Department of Health and Human Services, Centers for Disease Control and Prevention, National Institute for Occupational Safety and Health; 2004.

23. Skov T, Maarup B, Olsen J, Rorth M, Winthereik H, Lynge E: Leukaemia and reproductive outcome among nurses handling antineoplastic drugs. $\mathrm{Br} J$ Ind Med 1992, 49:855-861.

24. Skov T, Lynge E, Maarup B, Olsen J, Rorth M, Winthereik H: Risks for physicians handling antineoplastic drugs. Lancet 1990, 336:1446.

25. Ratner PA, Spinelli JJ, Beking K, Lorenzi M, Chow Y, Teschke K, Le ND, Gallagher RP, Dimich-Ward H: Cancer incidence and adverse pregnancy outcome in registered nurses potentially exposed to antineoplastic drugs. BMC Nurs 2010, 9:15.

26. McDiarmid MA, Oliver MS, Roth TS, Rogers B, Escalante C: Chromosome 5 and 7 abnormalities in oncology personnel handling anticancer drugs. J Occup Environ Med 2010, 52:1028-1034.

27. Rahu M, Rahu K, Auvinen A, Tekkel M, Stengrevics A, Hakulinen T, Boice JD Jr, Inskip PD: Cancer risk among Chernobyl cleanup workers in Estonia and Latvia, 1986-1998. Int J Cancer 2006, 119:162-168.

28. Abramenko I, Bilous N, Chumak A, Davidova E, Kryachok I, Martina Z, Nechaev S, Dyagil I, Bazyka D, Bebeshko V: Chronic lymphocytic leukemia patients exposed to ionizing radiation due to the Chernobyl NPP accident-with focus on immunoglobulin heavy chain gene analysis.

Leuk Res 2008, 32:535-545.

29. Romanenko A, Bebeshko V, Hatch M, Bazyka D, Finch S, Dyagil I, Reiss R, Chumak V, Bouville A, Gudzenko N, et al: The Ukrainian-American study of leukemia and related disorders among Chornobyl cleanup workers from Ukraine: I. Study methods. Radiat Res 2008, 170:691-697.

30. Romanenko AY, Finch SC, Hatch M, Lubin JH, Bebeshko VG, Bazyka DA, Gudzenko N, Dyagil IS, Reiss RF, Bouville A, et al: The Ukrainian-American study of leukemia and related disorders among Chornobyl cleanup workers from Ukraine: III. Radiation risks. Radiat Res 2008, 170:711-720.

31. Kesminiene A, Evrard AS, Ivanov VK, Malakhova IV, Kurtinaitis J, Stengrevics A, Tekkel M, Anspaugh LR, Bouville A, Chekin S, et al: Risk of hematological malignancies among Chernobyl liquidators. Radiat Res 2008, 170:721-735.

32. Boice JD, Cohen SS, Mumma MT, Dupree Ellis E, Eckerman KF, Leggett RW, Boecker $\mathrm{BB}$, Brill AB, Henderson BE: Mortality among radiation workers at Rocketdyne (Atomics International), 1948-1999. Radiat Res 2006, 166:98-115.

33. Richardson DB, Wing S, Wolf S: Mortality among workers at the Savannah River Site. Am J Ind Med 2007, 50:881-891.

34. Richardson DB, Wing S: Leukemia mortality among workers at the Savannah River Site. Am J Epidemiol 2007, 166:1015-1022.

35. Schubauer-Berigan MK, Daniels RD, Fleming DA, Markey AM, Couch JR, Ahrenholz SH, Burphy JS, Anderson JL, Tseng CY: Risk of chronic myeloid and acute leukemia mortality after exposure to ionizing radiation among workers at four U.S. nuclear weapons facilities and a nuclear naval shipyard. Radiat Res 2007, 167:222-232.

36. Schubauer-Berigan MK, Daniels RD, Fleming DA, Markey AM, Couch JR, Ahrenholz SH, Burphy JS, Anderson JL, Tseng CY: Chronic lymphocytic leukaemia and radiation: findings among workers at five US nuclear facilities and a review of the recent literature. Br J Haematol 2007, 139:799-808. 
37. Matanoski GM, Tonascia JA, Correa-Villasenor A, Yates KC, Fink N, Elliott E, Sanders B, Lantry D: Cancer risks and low-level radiation in U.S. shipyard workers. J Radiat Res (Tokyo) 2008, 49:83-91.

38. Ashmore JP, Gentner NE, Osborne RV: Incomplete data on the Canadian cohort may have affected the results of the study by the International Agency for Research on Cancer on the radiogenic cancer risk among nuclear industry workers in 15 countries. J Radiol Prot 2010, 30:121-129.

39. Lie JA, Kjaerheim K, Tynes T: lonizing radiation exposure and cancer risk among Norwegian nurses. Eur J Cancer Prev 2008, 17:369-375.

40. Samerdokiene V, Atkocius V, Valuckas KP: The risk of cancer among Lithuanian medical radiation workers in 1978-2004. Medicina (Kaunas) 2009, 45:412-418.

41. Ramos M, Montoro A, Almonacid M, Ferrer S, Barquinero JF, Tortosa R, Verdu G, Rodriguez P, Barrios L, Villaescusa Jl: Radiation effects in interventional radiology using biological and physical dosimetry methods: a case-control study. Conf Proc IEEE Eng Med Biol Soc 2008, 2008:2809-2812

42. Ramos M, Montoro A, Almonacid M, Ferrer S, Barquinero JF, Tortosa R, Verdu G, Rodriguez P, Barrios LL, Villaescusa Jl: Radiation effects analysis in a group of interventional radiologists using biological and physical dosimetry methods. Eur J Radiol 2009, 75:259-264.

43. Ahn YS, Park RM, Koh DH: Cancer admission and mortality in workers exposed to ionizing radiation in Korea. J Occup Environ Med 2008, 50:791-803.

44. Storm HH, Jorgensen HO, Kejs AM, Engholm G: Depleted uranium and cancer in Danish Balkan veterans deployed 1992-2001. Eur J Cancer 2006, 42:2355-2358

45. Mohner $M$, Lindtner M, Otten H, Gille HG: Leukemia and exposure to ionizing radiation among German uranium miners. Am J Ind Med 2006, 49:238-248.

46. Mohner M, Gellissen J, Marsh JW, Gregoratto D: Occupational and diagnostic exposure to ionizing radiation and leukemia risk among German uranium miners. Health Phys 2010, 99:314-321.

47. Roosli M, Lortscher M, Egger M, Pfluger D, Schreier N, Lortscher E, Locher $\mathrm{P}$, Spoerri A, Minder C: Leukaemia, brain tumours and exposure to extremely low frequency magnetic fields: cohort study of Swiss railway employees. Occup Environ Med 2007, 64:553-559.

48. Kheifets L, Monroe J, Vergara X, Mezei G, Afifi AA: Occupational electromagnetic fields and leukemia and brain cancer: an update to two meta-analyses. J Occup Environ Med 2008, 50:677-688.

49. Zhang L, Rothman N, Li G, Guo W, Yang W, Hubbard AE, Hayes RB, Yin S, Lu W, Smith MT: Aberrations in chromosomes associated with lymphoma and therapy-related leukemia in benzene-exposed workers. Environ $\mathrm{Mol}$ Mutagen 2007, 48:467-474

50. Richardson DB: Multistage modeling of leukemia in benzene workers: a simple approach to fitting the 2-stage clonal expansion model. Am J Epidemiol 2009, 169:78-85.

51. Rushton L, Brown TP, Cherrie J, Fortunato L, Van Tongeren M, Hutchings SJ: How much does benzene contribute to the overall burden of cancer due to occupation? Chem Biol Interact 2009, 184:290-292.

52. Costantini AS, Benvenuti A, Vineis P, Kriebel D, Tumino R, Ramazzotti V, Rodella S, Stagnaro E, Crosignani P, Amadori D, et al: Risk of leukemia and multiple myeloma associated with exposure to benzene and other organic solvents: evidence from the Italian Multicenter Case-control study. Am J Ind Med 2008, 51:803-811.

53. Cocco P, t'Mannetje A, Fadda D, Melis M, Becker N, de Sanjose S, Foretova L, Mareckova J, Staines A, Kleefeld S, et al: Occupational exposure to solvents and risk of lymphoma subtypes: results from the Epilymph case-control study. Occup Environ Med 2010, 67:341-347.

54. Lehman EJ, Hein MJ: Mortality of workers employed in shoe manufacturing: an update. Am J Ind Med 2006, 49:535-546.

55. Atallah E, Schiffer CA: Agent Orange, prostate cancer irradiation and acute promyelocytic leukemia (APL): is there a link? Leuk Res 2007, 31:720-721.

56. Collins JJ, Bodner $\mathrm{K}$, Aylward LL, Wilken M, Bodnar CM: Mortality rates among trichlorophenol workers with exposure to $2,3,7,8$ tetrachlorodibenzo-p-dioxin. Am J Epidemio/ 2009, 170:501-506.

57. Delzell E, Sathiakumar N, Graff J, Macaluso M, Maldonado G, Matthews R: An updated study of mortality among North American synthetic rubber industry workers. Res Rep Health Eff Inst 2006(132):1-63. discussion 65-74.
58. Beall C, Corn M, Cheng H, Matthews R, Delzell E: Mortality and cancer incidence among tire manufacturing workers hired in or after 1962. J Occup Environ Med 2007, 49:680-690.

59. Cheng H, Sathiakumar N, Graff J, Matthews R, Delzell E: 1,3-Butadiene and leukemia among synthetic rubber industry workers: exposure-response relationships. Chem Biol Interact 2007, 166:15-24.

60. Sathiakumar N, Delzell E: A follow-up study of women in the synthetic rubber industry: study methods. Chem Biol Interact 2007, 166:25-28.

61. Sathiakumar N, Delzell E: A follow-up study of mortality among women in the North American synthetic rubber industry. J Occup Environ Med 2009, 51:1314-1325.

62. Beane Freeman LE, Blair A, Lubin JH, Stewart PA, Hayes RB, Hoover RN, Hauptmann M: Mortality from lymphohematopoietic malignancies among workers in formaldehyde industries: the National Cancer Institute Cohort. J Natl Cancer Inst 2009, 101:751-761.

63. Hauptmann M, Stewart PA, Lubin JH, Beane Freeman LE, Hornung RW, Herrick RF, Hoover RN, Fraumeni JF Jr, Blair A, Hayes RB: Mortality from lymphohematopoietic malignancies and brain cancer among embalmers exposed to formaldehyde. J Natl Cancer Inst 2009, 101:1696-1708.

64. Zhang L, Tang X, Rothman N, Vermeulen R, Ji Z, Shen M, Qiu C, Guo W, Liu $S$, Reiss B, et al: Occupational exposure to formaldehyde, hematotoxicity, and leukemia-specific chromosome changes in cultured myeloid progenitor cells. Cancer Epidemiol Biomarkers Prev 2010, 19:80-88.

65. Speit G, Gelbke HP, Pallapies D, Morfeld P: Occupational exposure to formaldehyde, hematotoxicity and leukemia-specific chromosome changes in cultured myeloid progenitor cells. Cancer Epidemiol Biomarkers Prev 2010, 19:1882-1884. author reply 1884-1885.

66. Lam TV, Agovino P, Niu X, Roche L: Linkage study of cancer risk among lead-exposed workers in New Jersey. Sci Total Environ 2007, 372:455-462.

67. Mahajan R, Blair A, Lynch CF, Schroeder P, Hoppin JA, Sandler DP, Alavanja $M C$ : Fonofos exposure and cancer incidence in the agricultural health study. Environ Health Perspect 2006, 114:1838-1842.

68. Mahajan R, Bonner MR, Hoppin JA, Alavanja MC: Phorate exposure and incidence of cancer in the agricultural health study. Environ Health Perspect 2006, 114:1205-1209.

69. Miligi L, Costantini AS, Veraldi A, Benvenuti A, Vineis P: Cancer and pesticides: an overview and some results of the Italian multicenter case-control study on hematolymphopoietic malignancies. Ann N Y Acad Sci 2006, 1076:366-377.

70. Hansen ES, Lander F, Lauritsen JM: Time trends in cancer risk and pesticide exposure, a long-term follow-up of Danish gardeners. Scand J Work Environ Health 2007, 33:465-469.

71. Purdue MP, Hoppin JA, Blair A, Dosemeci M, Alavanja MC: Occupational exposure to organochlorine insecticides and cancer incidence in the Agricultural Health Study. Int J Cancer 2007, 120:642-649.

72. van Bemmel DM, Visvanathan K, Beane Freeman LE, Coble J, Hoppin JA, Alavanja MC: S-ethyl-N,N-dipropylthiocarbamate exposure and cancer incidence among male pesticide applicators in the agricultural health study: a prospective cohort. Environ Health Perspect 2008, 116:1541-1546.

73. Chrisman Jde R, Koifman S, de Novaes Sarcinelli P, Moreira JC, Koifman RJ, Meyer A: Pesticide sales and adult male cancer mortality in Brazil. Int J Hyg Environ Health 2009, 212:310-321.

74. Delancey JO, Alavanja MC, Coble J, Blair A, Hoppin JA, Austin HD, Beane Freeman LE: Occupational exposure to metribuzin and the incidence of cancer in the Agricultural Health Study. Ann Epidemiol 2009, 19:388-395.

75. Orsi L, Delabre L, Monnereau A, Delval P, Berthou C, Fenaux P, Marit G, Soubeyran P, Huguet F, Milpied N, et al: Occupational exposure to pesticides and lymphoid neoplasms among men: results of a French case-control study. Occup Environ Med 2009, 66:291-298.

76. Rusiecki JA, Patel R, Koutros S, Beane-Freeman L, Landgren O, Bonner MR, Coble J, Lubin J, Blair A, Hoppin JA, Alavanja MC: Cancer incidence among pesticide applicators exposed to permethrin in the Agricultural Health Study. Environ Health Perspect 2009, 117:581-586.

77. Bassil KL, Vakil C, Sanborn M, Cole DC, Kaur JS, Kerr KJ: Cancer health effects of pesticides: systematic review. Can Fam Physician 2007 53:1704-1711.

78. Moore T, Brennan P, Becker N, de Sanjose S, Maynadie M, Foretova L, Cocco $P$, Staines A, Nieters A, Font R, et al: Occupational exposure to meat and risk of lymphoma: a multicenter case-control study from Europe. Int J Cancer 2007, 121:2761-2766. 
79. Johnson ES, Ndetan H, Lo KM: Cancer mortality in poultry slaughtering/ processing plant workers belonging to a union pension fund. Environ Res 2010, 110:588-594

80. Johnson ES, Zhou Y, Lillian Yau C, Prabhakar D, Ndetan H, Singh K, Preacely $\mathrm{N}$ : Mortality from malignant diseases-update of the Baltimore union poultry cohort. Cancer Causes Control 2010, 21:215-221.

81. Dimich-Ward H, Lorenzi M, Teschke K, Spinelli JJ, Ratner PA, Le ND, Chow Y, Shu D, Gallagher RP: Mortality and cancer incidence in a cohort of registered nurses from British Columbia, Canada. Am J Ind Med 2007, 50:892-900.

82. Abel GA, Bertrand KA, Earle CC, Laden F: Outcomes for lymphoid malignancies in the Nurses' Health Study (NHS) as compared to the Surveillance, Epidemiology and End Results (SEER) Program. Hematol Oncol 2009, 28:133-136.

83. Lollis SS, Valdes PA, Li Z, Ball PA, Roberts DW: Cause-specific mortality among neurosurgeons. J Neurosurg 2010, 113:474-478.

84. Kubale T, Hiratzka S, Henn S, Markey A, Daniels R, Utterback D, Waters K, Silver S, Robinson C, Macievic G, Lodwick J: A cohort mortality study of chemical laboratory workers at Department of Energy Nuclear Plants. Am J Ind Med 2008, 51:656-667.

85. Bates MN: Registry-based case-control study of cancer in California firefighters. Am J Ind Med 2007, 50:339-344.

86. Huebner WW, Wojcik NC, Jorgensen G, Marcella SP, Nicolich MJ: Mortality patterns and trends among 127,266 U.S.-based men in a petroleum company: update 1979-2000. J Occup Environ Med 2009, 51:1333-1348.

87. Gazdek D, Strnad M, Mustajbegovic J, Nemet-Lojan Z Lymphohematopoietic malignancies and oil exploitation in KoprivnicaKrizevci County, Croatia. Int J Occup Environ Health 2007, 13:258-267.

88. Iaia TE, Bartoli D, Calzoni P, Comba P, De Santis M, Dini F, Farina GA, Valian M, Pirastu R: A cohort mortality study of leather tanners in Tuscany, Italy. Am J Ind Med 2006, 49:452-459.

89. Firth H, Gray A, Carpenter LM, Cox B: Cancer mortality by occupation among New Zealand women: 1988-1997. N Z Med J 2007, 120:U2833.

90. Hoffmann W, Terschueren C, Heimpel H, Feller A, Butte W, Hostrup O, Richardson D, Greiser E: Population-based research on occupational and environmental factors for leukemia and non-Hodgkin's lymphoma: the Northern Germany Leukemia and Lymphoma Study (NLL). Am J Ind Med 2008, 51:246-257.

91. Richardson DB, Terschuren C, Hoffmann W: Occupational risk factors for non-Hodgkin's lymphoma: a population-based case-control study in Northern Germany. Am J Ind Med 2008, 51:258-268.

92. Kaufman DW, Anderson TE, Issaragrisil S: Risk factors for leukemia in Thailand. Ann Hematol 2009, 88:1079-1088.

93. McLean D, Mannetje A, Dryson E, Walls C, McKenzie F, Maule M, Cheng S, Cunningham C, Kromhout $\mathrm{H}$, Boffetta $\mathrm{P}$, et al: Leukaemia and occupation: a New Zealand Cancer Registry-based case-control Study. Int J Epidemiol 2009, 38:594-606.

94. Pearce MS, Hammal DM, Dorak MT, McNally RJ, Parker L: Paternal occupational exposure to pesticides or herbicides as risk factors for cancer in children and young adults: a case-control study from the North of England. Arch Environ Occup Health 2006, 61:138-144.

95. Pearce MS, Hammal DM, Dorak MT, McNally RJ, Parker L: Paternal occupational exposure to electro-magnetic fields as a risk factor for cancer in children and young adults: a case-control study from the North of England. Pediatr Blood Cancer 2007, 49:280-286.

96. McKinney PA, Raji OY, van Tongeren M, Feltbower RG: The UK Childhood Cancer Study: maternal occupational exposures and childhood leukaemia and lymphoma. Radiat Prot Dosimetry 2008, 132:232-240.

97. Perez-Saldivar ML, Ortega-Alvarez MC, Fajardo-Gutierrez A, Bernaldez-Rios R, Del Campo-Martinez Mde L, Medina-Sanson A, Palomo-Colli MA, ParedesAguilera R, Martinez-Avalos A, Borja-Aburto VH, et al: Father's occupational exposure to carcinogenic agents and childhood acute leukemia: a new method to assess exposure (a case-control study). BMC Cancer 2008, 8:7.

98. Telle-Lamberton M, Samson E, Caer S, Bergot D, Bard D, Bermann F, Gelas JM, Giraud JM, Hubert P, Metz-Flamant C, et al: External radiation exposure and mortality in a cohort of French nuclear workers. Occup Environ Med 2007, 64:694-700.

99. Gilbert ES: Invited commentary: studies of workers exposed to low doses of radiation. Am J Epidemiol 2001, 153:319-322. discussion 323-314.

100. Howe GR: Leukemia following the Chernobyl accident. Health Phys 2007, 93:512-515.
101. Lagorio S, Grande E, Martina L: Review of epidemiological studies of cancer risk among Gulf War and Balkans veterans. Epidemiol Prev 2008, 32:145-155

102. Macfarlane GJ, Biggs AM, Maconochie N, Hotopf M, Doyle P, Lunt M: Incidence of cancer among UK Gulf war veterans: cohort study. BMJ 2003, 327:1373.

103. Kim EA, Lee WJ, Son M, Kang SK: Occupational lymphohematopoietic cancer in Korea. J Korean Med Sci 2010, 25:S99-S104.

104. Final Report on Carcinogens Background Document for Formaldehyde. Rep Carcinog Backgr Doc 2010:i-512. http://ntp.niehs.nih.gov/ntp/roc/ twelfth/2009/november/formaldehyde_bd_final.pdf.

105. Kupczewska-Dobecka M: Assessment of carcinogenicity of formaldehyde based on the newest literature data. Med Pr 2007, 58:527-539.

106. Collins JJ, Lineker GA: A review and meta-analysis of formaldehyde exposure and leukemia. Regul Toxicol Pharmacol 2004, 40:81-91.

107. Golden R, Pyatt D, Shields PG: Formaldehyde as a potential human leukemogen: an assessment of biological plausibility. Crit Rev Toxicol 2006, 36:135-153.

108. Zhang L, Steinmaus C, Eastmond DA, Xin XK, Smith MT: Formaldehyde exposure and leukemia: a new meta-analysis and potential mechanisms. Mutat Res 2009, 681:150-168.

109. Schwilk E, Zhang L, Smith MT, Smith AH, Steinmaus C: Formaldehyde and leukemia: an updated meta-analysis and evaluation of bias. $J$ Occup Environ Med 2010, 52:878-886.

110. Cole P, Adami HO, Trichopoulos D, Mandel JS: Re: Mortality from lymphohematopoietic malignancies and brain cancer among embalmers exposed to formaldehyde. J Natl Cancer Inst 2010, 102:1518-1519. author reply $1519-1520$

111. Goldstein BD: Hematological and toxicological evaluation of formaldehyde as a potential cause of human leukemia. Hum Exp Toxicol 2011, 30:725-735.

112. Svec MA, Ward MH, Dosemeci M, Checkoway H, De Roos AJ: Risk of lymphatic or haematopoietic cancer mortality with occupational exposure to animals or the public. Occup Environ Med 2005, 62:726-735.

113. Fritschi $L$, Johnson KC, Kliewer EV, Fry R: Animal-related occupations and the risk of leukemia, myeloma, and non-Hodgkin's lymphoma in Canada. Cancer Causes Control 2002, 13:563-571.

114. McLean D, Pearce N: Cancer among meat industry workers. Scand J Work Environ Health 2004, 30:425-437.

115. Wong O, Harris F, Armstrong TW, Hua F: A hospital-based case-control study of acute myeloid leukemia in Shanghai: analysis of environmental and occupational risk factors by subtypes of the WHO classification. Chem Biol Interact 2010, 184:112-128.

doi:10.1186/1745-6673-8-14

Cite this article as: Polychronakis et al:: Work-related leukemia: a systematic review. Journal of Occupational Medicine and Toxicology 2013 $8: 14$

\section{Submit your next manuscript to BioMed Central and take full advantage of:}

- Convenient online submission

- Thorough peer review

- No space constraints or color figure charges

- Immediate publication on acceptance

- Inclusion in PubMed, CAS, Scopus and Google Scholar

- Research which is freely available for redistribution 